\title{
THE UNDERREPRESENTATION AND THE DISINTEREST OF MALAY WOMEN IN NURSING IN THE EARLY POST-COLONIAL MALAYSIA (1957-1977): A CULTURAL PERSPECTIVE
}

(Kurangnya Penglibatan dan Minat Wanita Melayu dalam Bidang Kejururawatan pada Awal Pascakolonial Malaysia (1957-1977): Perspektif Budaya)

Salilah Saidun

s_salilah@yahoo.com

Department of History and Civilization, Kuliyyah of Islamic Revealed Knowledge and Human Sciences, International Islamic University Malaysia.

Rujukan artikel ini (To cite this article): Salilah Saidun. (2021). The underrepresentation and the disinterest of Malay women in nursing in the early post-colonial Malaysia (1957-1977). Melayu: Jurnal Antarabangsa Dunia Melayu, 14(2), 181-200. http://doi.org. 10.37052/jm.14(2)no2

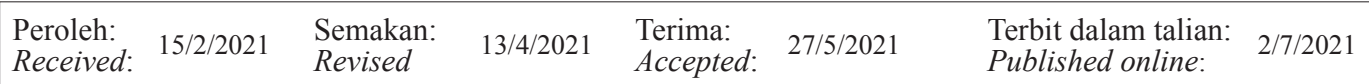

\begin{abstract}
Abstrak
Modern nursing started in Malaysia during the colonial rule and with embedded colonial values. During the first two decades of post-independent Malaysia, the Malays were a minority in the nursing workforce despite being the majority population. This study examines the issue of this paradoxical underrepresentation of Malay women from the lens of Malay culture during this period. Document analysis was conducted on relevant annual reports, official letters, minute papers, newspaper articles and parliamentary debates official reports between 1957 and 1977. The findings suggest that the underrepresentation of the Malays in nursing was predominantly due to the disinterest of Malay women to become nurses due to the discordance between the Malay culture and various aspects of nursing. This article highlights the importance of a culturally sensitive work environment in promoting inclusivity for the diverse members of the society.
\end{abstract}

Keyword: Nursing, Malay women, post-colonial, inclusivity, diversity

(C) Dewan Bahasa dan Pustaka. 2021. This work is licensed under the term of the Creative Commons Attribution (CC BY) (http://creative commons.org/licenses/by/4.0/)

ISSN 1675-6460 e-ISSN 2682-8049 


\section{Abstract}

Kejururawatan moden bermula di Tanah Melayu ketika era kolonial dengan nilai-nilai kolonial terpasak bersama-samanya. Ketika dua dekad pertama pascakemerdekaan Malaysia, kaum Melayu merupakan golongan minoriti dalam sektor kejururawatan biarpun kaum Melayu merupakan golongan majoriti dalam populasi. Kajian ini membincangkan isu paradoks kekurangan penglibatan wanita Melayu ini dari lensa budaya Melayu dalam tempoh tersebut. Analisis dokumen dijalankan terhadap laporan tahunan, surat rasmi, kertas minit, laporan akhbar dan penyata rasmi parlimen antara tahun 1957 hingga 1977. Dapatan kajian menunjukkan bahawa kekurangan pelibatan kaum Melayu dalam sektor kejururawatan disebabkan oleh kurangnya minat wanita Melayu untuk menjadi jururawat kerana pertentangan antara budaya Melayu dengan pelbagai aspek kejururawatan moden. Artikel ini menunjukkan kepentingan suasana kerja yang mesra budaya dalam hal mempromosikan keterangkuman untuk ahli rencam latar dalam masyarakat.

Kata kunci: kejururawatan, wanita Melayu, pasca-kolonial, keterangkuman, kerencaman

\section{INTRODUCTION}

Underrepresentation of groups of individuals is a long-standing global phenomenon in education, employment and other domains. Underrepresentation occurs on the basis of race, ethnicity, religion, age, gender, socioeconomic status, health status (such as physical and mental disabilities) and other demographics. The issue has been discussed in the academic literature at least since the nineteenth century (Gidley, Hampson, Wheeler, \& Bereded-Samuel, 2010). To ensure equitable representation of numerous social groupings, social inclusion is currently promoted in many countries (Gidley et al., 2010).

To date, social inclusion is deliberated based on a few theories and ideologies. The neoliberalists are concerned with the national interest and advocates for the improvement of human capital - by providing adequate access - which would be beneficial for the economy. On the other hand, the social justice ideology advocates for an egalitarian society whose members have equal rights and opportunities to participate in any domain. Another group of ideology asserts that social inclusion is not just for the sake of social justice but also necessary to empower the potential of every human being. Within this ideology, embracing cultural diversity is seen as a form of empowerment in the process of development in the post-colonial era (Gidley et al., 2010). 
In nursing, underrepresentation of specific racial or ethnic groups exists in many countries in both its education and employment spheres (Greer, 1995). Ensuring equitable representation is imperative not only for social ethical reasons but also to help reduce health disparities among their social groups (Greer, 1995; Phillips \& Malone, 2014). In the case of Malaysia, the relatively lower health status of the Malays compared to other races in Malaysia during the early post-independence period was believed to be caused by, amongst others, the underrepresentation of the Malays in the healthcare workforce (Berita Harian, 1960). The mechanism of how socially inclusive healthcare workforce would lead to health equity is likely through

Table 1 Number of registered nurses in Malaysia

\begin{tabular}{|c|c|c|c|c|c|c|c|c|c|c|c|}
\hline Year & 1957 & 1958 & 1959 & 1963 & 1964 & 1966 & 1967 & 1971 & 1972 & 1973 & 1974 \\
\hline $\begin{array}{l}\text { Gov- } \\
\text { ern- } \\
\text { ment } \\
\text { nurses }\end{array}$ & 1,411 & 1,345 & 1,427 & 1,239 & 1,471 & NA & 2,143 & 2,487 & 2,711 & 3,059 & 3,621 \\
\hline $\begin{array}{c}- \\
\text { Malay }\end{array}$ & *NA & NA & NA & $\begin{array}{c}93 \\
(8 \%)\end{array}$ & NA & NA & NA & NA & NA & $\begin{array}{c}604 \\
(20 \%)\end{array}$ & $\begin{array}{l}1,076 \\
(30 \%)\end{array}$ \\
\hline $\begin{array}{l}\text { Other } \\
\text { nurses }\end{array}$ & 200 & 158 & 212 & NA & NA & NA & NA & 3,012 & 3,320 & 3,744 & 4,209 \\
\hline $\begin{array}{c}- \\
\text { Malay }\end{array}$ & NA & NA & NA & NA & NA & NA & NA & NA & NA & NA & NA \\
\hline Total & 1,611 & 1,503 & 1,639 & NA & NA & 3,000 & NA & 5,499 & 6,031 & 6,803 & 7,830 \\
\hline $\begin{array}{c}- \\
\text { Malay }\end{array}$ & $\begin{array}{c}118 \\
(7 \%)\end{array}$ & $\begin{array}{c}149 \\
(10 \%)\end{array}$ & $\begin{array}{c}148 \\
(9 \%)\end{array}$ & NA & NA & $\begin{array}{c}324 \\
(11 \%)\end{array}$ & NA & $\begin{array}{c}363 \\
(7 \%)\end{array}$ & $\begin{array}{c}416 \\
(7 \%)\end{array}$ & NA & NA \\
\hline
\end{tabular}

*NA: not available

Source: Medical and Health Department (1958, p.64), Medical and Health Department (1959, p.55), Medical and Health Department (1960, p.54), Parliament of Malaysia (1964), Ministry of Health Malaysia (1973), Ministry of Health Malaysia (1975, p.183), Berita Harian (1963c), Berita Harian (1966b).

Note: No annual report of the Ministry of Health found from 1960 to 1970. 
improved communication (due to language and culturally-sensitive interaction), expanded services to the social group, increased advocacy program and increased trust of the social group towards the healthcare system (Williams et al., 2014). Numerous challenges faced by student nurses from underrepresented groups have been reported in the literature. A review article on the issue cited cultural insensitivity of the nursing training programs as one of the barriers to becoming nurses, as depicted by four studies (Loftin, Newman, Dumas, Gilden, \& Bond, 2012). Thus, a culturally sensitive environment is an imperative aspect of an inclusive policy for the specific target group.

Although minority underrepresentation occurs more commonly, the paradoxical phenomenon of underrepresentation of the majority population also exists. The Malaysian nursing profession had this issue during the early decades after Malaysia gained its independence. Malay women were encouraged to join nursing since the pre-independence period as the government recognised the importance of involving the native population in healthcare (Selangor State Council, 1933; Chief Medical Officer of Terengganu, 1951; State Medical and Health Officer of Perak, 1956). Hence, employing adequate Malay nurses would allow better service delivery, health education and health promotion in the Malay community (Idris, 2016: 401-412). Yet, the percentage of Malay nurses remained low during the first two decades after independence, as shown in Table 1. This paradox suggests that the underrepresentation was likely due to the disinterest of the Malays to join nursing despite having adequate access and opportunity (Berita Harian, 1957b). Even though Malay women were involved in the labour workforce, many of them were interested in the teaching profession while nursing remained unpopular (Berita Harian, 1964b; Mariam, 1959). Knowledge of the factors for the disinterest of the Malay women to join nursing may allow understanding of this historical phenomenon but no previous study has examined the issue.

The purpose of this paper is to examine the factors of the low percentage of Malay nurses during the early post-independence period. Midwifery is excluded from the scope of the paper as midwifery was more congruous with the Malay culture in multiple dimensions. Firstly, unlike nursing, the Malays were familiar with traditional midwifery, which has long been accepted as a noble occupation for women. Secondly, midwives do not provide care for male patients. Thirdly, government midwives were allowed to wear Baju Kurung Kedah (a traditional Malay attire, which consists of a three-quarter-sleeved top and an ankle-length straight cut skirt called sarong) (Ministry of Health, 2017). Fourthly, the requirement for acceptance into the midwifery program (including the English language competency) was 
lower compared to nursing (Chief Medical Officer of Terengganu, 1953). Hence, the reception for midwifery was better than that of nursing. The timeline between 1957 and 1977 is chosen due to the phenomenon of paradoxical underrepresentation of Malay in nursing while the Federation of Malaya (and later known as Malaysia since 1963) had attained political independence and were able to formulate its own policies suitable for the nation and its people. The year 1977 is also chosen as the final timeframe because the midwife scheme was combined with the assistant nurse scheme to become the rural nurse (jururawat desa) scheme and the first batch intake of village nurses started their training in 1977 (Prime Minister's Office, 1976: 418). Although the disinterest to join nursing was likely a result of multiple factors, the scope of the paper is limited to cultural factors. Hence, this paper will deliberate the issue within the framework of deprivation of cultural needs in the post-colonial era which possibly resulted in disempowerment that led to the underrepresentation.

Data collection was done through library research. The Boolean search was conducted in the National Archives database, online newspaper database and parliamentary debates official report database in English and the Malay language during the timeframe. Relevant annual reports, official letters, minute papers, newspaper articles and parliamentary debates official reports underwent document analysis to identify the possible cultural factors for the disinterest of Malay women in joining nursing.

\section{CULTURAL FACTORS BEHIND THE DISINTEREST OF MALAYS IN NURSING}

In order to understand the cultural factors that led to the underrepresentation of Malays in the Malaysian nursing workforce, the paper will first discuss the status of culture in the lives of the Malays. The Malays are the majority native group inhabiting Malaysia. The cultural practices among the Malays were described in the nineteenth century by the writings of Sir Frank Athelstane Swettenham (1850-1946), the first British Resident General of the Federated Malay States, in his book entitled The Malay Sketches. Swettenham observed the Malays as Muslims who highly respected their customs, even greater than their adherence to their religion (Swettenham, 1895). To understand the status of culture in the lives of Malays in modern Malaysia, we shall look at the definition of "Malay" in the Federal Constitution. Article 160 (2) of the Federal Constitution of Federation of Malaya (later became the Federal Constitution of Malaysia) defines a Malay as: 
A person who professes the religion of Islam, habitually speaks the Malay language, conforms to Malay custom and was before Merdeka (Independence) Day born in the Federation or in Singapore or born of parents one of whom was born in the Federation or in Singapore, or is on that day domiciled in the Federation or in Singapore, or is the issue of such a person (Federal Constitution, 1957; 2010).

This suggests that culture is an integral aspect in the lives of the Malays, even more than religion as the practice of religion is not specifically mentioned in the defining criteria, compared to conformance to the Malay customs. Thus, cultural factors may have played significant roles in the choice of career among employed Malay women. The paper does not deny the presence of other non-cultural factors that made nursing an unpopular profession such as low wages, high responsibility and other unfavourable features (Berita Harian, 1964b) but the scope of the paper is limited to the cultural factors. At the same time, there were cultural factors that were compatible with nursing practices such as the women-friendly features of nursing which involve serving, cleaning and caring (Ramli, 2004). However, the scope of the paper is focused on the cultural factors that were incongruent with nursing which likely contributed to the disinterest and underrepresentation of Malays.

In deliberating the cultural factors that possibly led to the underrepresentation, the Malay culture is first described to provide a contextual insight before the situation in nursing is discussed in each subsection. The cultural practices of Malay communities in different geographical areas are not homogenous and reporting all the practices requires a lengthy discussion. Hence, the paper only discusses the general known cultural practices related to the issue. The discussion is also limited to the cultural context within the period of the study (1957-1977).

\section{Disinterest in Modern Healthcare}

The Malays has been practising traditional and religious healing for centuries. Shamans and religious healers were consulted for healing, though traditionally processed medicines and rituals (Parliament of Malaysia, 1964).

The Malays had prejudices over the modern healthcare system as it was introduced by the colonial government, managed by mainly non-Malay healthcare workers (doctors, nurses, and others), using modern lab-processed medicines, and operating based on different paradigms of diseases and healing (Berita Harian, 1960). Even if 
the younger generation at that time were exposed to modern education, the parents may have objected to their daughters' ambition to become nurses.

\section{Formal Language of Nursing}

The Malay Language is the mother tongue of Malays. The laissez-faire policy of the colonial government led to the establishment of five types of schools: the Malay vernacular schools, Islamic schools, English schools, Chinese schools and Tamil schools. The Malay vernacular schools taught the Malays reading, writing, counting and basic life skills in the Malay language (Othman \& Lee, 2014). Although English schools were opened to all, more than ninety per cent of the Malays did not attend these school (Hirschman, 1972) due to geographical limitations (only present in urban areas), economic limitations or concerns regarding the possibility of being influenced by Christianity doctrines as many of the schools were run by missionaries (Othman \& Lee, 2014; Saadon, Ariffin \& Saat, 2016). The percentage of Malay girls attending English schools was also lower compared to Malay boys (Ramli, 2004). The need for restructuring of the education system as the country was preparing for independence led to the issuance of the Razak Report in 1956, which proposed English as a compulsory second-language subject in all schools (Foo \& Richards, 2004; Tan, 2009). Although English was taught, the level of English proficiency among rural students was low (Foo and Richards, 2004) and two-thirds of the Malay population in the 1950s resided in rural areas (Berita Harian, 1959d).

Nurses from the United Kingdom served the Malayan healthcare service and at the same time trained the local student nurses prior to the Malaysian independence (Birks, Francis, Chapman, \& Abdullah, 2008). Hence, English was the official language for teaching, practising and also socialising as the healthcare workforce was dominated by the non-Malays. The linguistic disadvantage is a deterrent for Malays to join nursing (Berita Harian, 1959c). There were Malay women who were interested to become nurses but could not because of the English prerequisite. Hence, Che Khatijah Sidek (Member of Parliament who represented Dungun in 1959) proposed the annulment of the English prerequisite but her motion was rejected (Berita Harian, 1959d). In 1963, the Minister of Health, Abdul Rahman Talib announced that Malay-school leavers would be accepted in the nursing program the following year so that more Malays could become nurses (Berita Harian, 1963c). Later, materials for nursing training were also translated to the Malay Language in stages since 1970 (Parliament of Malaysia, 1972). 


\section{Training Locations and Posting Locations}

The family unit is important in Malay society. Unmarried women live with their parents or guardians and it is unfavourable in the Malay custom and etiquette to leave the house. Once married, Malay women lives with their husbands either in their parents' houses or independently but commonly still close to their parents. Married women would be reluctant to leave home and be away from their husbands and children, while more mature women (even if they do not exit the age limit for recruitment) would not be interested anymore even though they had more experience. It is common for Malay women to look after their parents especially when they are sick, even after they were married (Hirschman, 2016).

In the 1950s, there were only four nursing schools in Malaysia, situated in Johor, Penang, Kuala Lumpur and Malacca (Ministry of Health Malaysia, 1973; Parliament of Malaysia, 1974, 1975a). In the 1970s, two more schools were established in Kelantan and Perak under the Second Malaysia Plan (Ministry of Health Malaysia, 1973; Parliament of Malaysia, 1974). The duration of nursing training is 3 years and 4 months (Medical and Health Department, 1950; Malaysian Nursing Union, 1972: 61). In addition, under the Colombo Plan introduced in 1955 (Medical and Health Department, 1958), many nurses were sent for training overseas, such as to the United Kingdom, Australia, Hong Kong and Thailand (Berita Harian, 1958c, 1963a, 1966b, 1968a). Enrolling on the program means the women would likely need to stay far from their families during the course of the training. This may be challenging for them and their families.

Once qualified, nurses would be posted all over Malaysia (Berita Harian, $1957 \mathrm{~b})$. The possibility of being posted in rural areas was more unfavourable as the poor transport system and lack of facilities (Berita Harian, 1967) would further complicate their interaction with their families. For married women, the patriarchal custom and the main breadwinning role of the husband (Hirschman, 2016) means that the women usually follow their husbands where they work and not the other way round. The unfavourable conditions of working in rural areas led to some nurses resigning when they were posted to the areas (Berita Harian, 1963f). Realising the problem, Muhammad Ujang, the political secretary of the Minister of Health in 1964 asserted that the Ministry would give priorities for Malays in the rural areas to join nursing as it will be easier for them to be posted to serve their own village once qualified (Berita Harian, 1964d). Besides that, nurses may request transfer after two years of service in the rural area or after nine months of service in remote rural areas (Parliament of Malaysia, 1973b). 


\section{Work-related Hazards}

Women in the Malay community were more guarded by male family members (Hirschman, 2016). Women were usually confined to areas near their houses and discouraged to go anywhere alone (Hirschman, 1972). This practice was influenced by both the patriarchal Malay custom and Islamic practices.

Nursing practice was not confined to the healthcare facilities, but nurses were also required to attend house calls. This exposed them to potential threats. There were cases of nurses who were harassed or assaulted physically (Berita Harian, 1957a, 1959a, 1959b) and sexually by patients or the public (Berita Harian, 1962, 1964a; Parliament of Malaysia, 1965). Besides that, the nurse hostels were a common target for burglaries and harassments (Berita Harian, 1963d, 1963e, 1965a, 1965d). These hazards may worry the potential candidates and may deter their families from encouraging them to become nurses.

\section{Working Hours}

In the Malay household, domestic chores are mainly women's tasks. The Malay men are commonly helpful but the domestic sphere is still predominantly the women's domain even when they are employed, especially in terms of caring for children (Hirschman, 2016).

In nursing, the shift system requires nurses to be on duty during days or nights (Berita Harian, 1964b). This requires their spouses to look after their children during night shifts if the household does not have any domestic helpers because schools, kindergarten and childcare centres do not operate at night. Nightshifts further expose them to potential threats and harassment (Parliament of Malaysia, 1965). This situation adds to the unfavourable feature of nursing that may have led to the disinterest of Malays to join. During a parliamentary session in 1965, Ismail Idris, the then-Member of Parliament representing South Penang advocated for improved security for nurses on duty especially at night (Parliament of Malaysia, 1965).

\section{Nursing Uniform}

Although Malays are Muslims, the Malay dressing norm prior to the 1980s generally did not conform to the Islamic dressing rules. Throughout the centuries, the Malay women dressing norm evolved to various forms - from kemban (a piece of tubular cloth tied around the chest) to Baju Kurung (a long-sleeved loose straight-cut knee- 
length tunic top worn with a straight-cut ankle-length skirt) to Kebaya (a longsleeved loose or tight top worn with a loose or tight ankle-length skirt). Despite the evolution, the minimum extent of coverage has been consistent to at least cover from the chest to the ankle and later cover the upper limbs (Aris, 2014; Hassan, 2016; Shawal, 1994). Although the Islamic headscarf was rare in the 1950s, 1960s and 1970s (Tahir, 2003), the use of scarves to partially cover the hair was part of the Malay identity (Lee, 2014). The Malay traditional dress was considered appropriate for decent women. However, there was a group of Malays (who were educated by or serve the colonial government) who prefers modern clothing and perceived that the traditional dress is unsuitable for their socioeconomic status. (Lee, 2014).

The short-sleeved knee-length nurse uniform at that time contradicts the traditional Malay clothing norm (Parliament of Malaysia, 1959). The uniform was unacceptable for Malays who strongly conform to the cultural dressing, especially in the rural areas (Parliament of Malaysia, 1975c, 1977b, 1977a). The length of the uniform could not ensure adequate coverage of the wearer's body especially during movements such as squatting, running or bending (Parliament of Malaysia, 1976). The uniform was more uncomfortable for devout Malays who conformed to the Islamic clothing rules which mandate women to cover their whole body except the faces and hands. The uniform was changed in 1978 to allow nurses to either opt for the midi-gown uniform or the blouse-and-trousers uniform (Department of Information Malaysia, 1978).

\section{Cross-gender Interaction}

The Malays limit cross-gender contact by limiting unrelated men and women from seeing or speaking to each other unless necessary (Hirschman, 2016). Swettenham described how Malay girls were raised:

She (a Malay girl-child) runs wild till the time comes for investing her in a garment, that is to say when she is about five years old. From then, she is taught to help in the house and kitchen, to sew, to read and write, perhaps to work in the padi field, but she is kept out of the way of all strange men-kind. Unmarried girls are taught to avoid all men except those nearly related to them. Until marriage, it is considered unmaidenly for them to raise their eyes or take any part or interest in their surroundings when men are present. This leads to an affection of modesty ... (Swettenham, 1895). 
An example of this cross-gender interaction limitation can be seen in the architecture of traditional Malay houses, which separate the areas for entertaining male and female guests (Yusoff, Osman, Rofie, Abdul Rahman, \& Md Zain, 2004). The culture on cross-gender interaction limitation is one of the factors for low school attendance among Malay girls compared to Malay boys in the co-educational schools (Ramli, 2004). The responsibility to limit cross-gender interaction is a mutual responsibility but greater emphasis is placed on women (Ramli, 2004).

In nursing, part of the scope of work includes assisting doctors (who were mainly men during the period) and providing care for patients of any gender. Hence, nurses are required to touch the patients and see the body parts that are considered inappropriate to be seen (Berita Harian, 1958b). In the minute paper of the State Medical and Health Office of Selangor in 1938, the issue of Malay nurses requested to confine their service to only female patients were raised. Malay nurses who did not mind tending to male patients were still concerned about the perception of their families and relatives (State Medical and Health Office of Selangor, 1938). In the state of Terengganu, prior to independence, the State Secretary of Terengganu (1953) and Secretary of the Kuala Terengganu branch of the United Malays National Organisation (1954) submitted formal letters to the State Mufti (Muslim jurist), asking for his opinion on the cross-gender interaction between nurses and patients. The Secretary of the Kuala Terengganu branch of United Malays National Organisation also added a plea for the government to limit female nurses in providing care only for female patients. In his response letters, the Mufti highlighted the nobility of nursing and the permissibility of women to join nursing as the female Companions of Prophet Muhammad (peace be upon him) were actively involved in nursing at that time. However, the Mufti stated that it is impermissible for female nurses to provide care for male patients if male nurses (known as "dressers" at that time) are present. Yet, it is permissible to do so if male nurses are not present because it is considered a darurah (emergency). The Mufti also emphasised the need to ensure that those accepted in the nursing program have good characters to ensure that the patients are well taken care of and also suggested that the nurses are exposed to religious education (State Mufti of Terengganu, 1954a; 1954b).

Being aware of the Malay culture on cross-gender interaction, the government explicitly states that women who would like to join nursing must be ready to serve patients of any gender (Idris, 2016). This situation may be uncomfortable for some women. 


\section{No-marriage Rules during Training and the First Three Years Afterward}

During the early post-independent era, female members of the Malay society got married at a young age. The average ages at first marriage among Malay females in 1957 and 1970 were 17.9 and 21.1 years respectively. In 1957, 54.1\% of those aged between 15 and 19, and $90.6 \%$ those aged between 20 and 24 , and $97.6 \%$ of those aged between 25 and 29 were married. The statistics in 1970 were lower, with $22.7 \%$ of those aged between 15 and 19, and 67.6\% those aged between 20 and 24, and $91.3 \%$ of those aged between 25 and 29 were married (Elm and Hirschman, 1979). Being a spinster was considered unfavourable and were commonly stigmatised. Hence, parents usually married their daughters as soon as someone was interested in them.

The age requirement for nursing training was between 17.5 and 30 years (and later the upper limit was changed to 24 years), which are the suitable ages for getting married. However, the no-marriage rules were implemented during training (which lasted 3 years and 4 months) and during the first three years after training (Parliament of Malaysia, 1975b). The rules were unpleasant for women and there were instances where they started involving in illicit relationships, getting married secretly or decided to resign to get married legally (State Medical and Health Officer of Selangor, 1957; Parliament of Malaysia, 1975b).

\section{Associated Social Life (Leisure and Entertainment)}

Even though the Malay customs is not always in accordance with Islamic teaching, the Malays generally uphold the Islamic prohibition on alcohol consumption (Kortteinen, 2008; Swettenham, 1895). The Malays have a few types of traditional dances and the stances on the dances were split into a group who supported, while another group opposed the dances. The opposition group opined that decent women would not participate in dances, especially if it involves dancing with men (Putten, 2014).

Other than the nature of the profession itself, the social life of nurses outside working hours contradicted the Malay culture. It was the nurses' culture to organise annual parties or fundraising parties (Berita Harian, 1965c, 1966a; Malaysian Nursing Union, 1972: 23). These parties may involve alcoholic beverages, dances and socialisation with men (Berita Harian, 1958a, 1958b, 1963b). Outside working hours, it was common for nurses to wear attire that did not conform to the Malay clothing norm (Berita Harian, 1965b). Besides that, there were reported cases of illicit affairs involving nurses (Berita Harian, 1964c, 1968b). Although one may 
argue that the lifestyle is a choice and not part of the working environment, it may still inflict peer pressure for nurses to conform to the group lifestyle, which was unfavourable for the Malays.

Due to the negative image, there were efforts to provide religious education to nurses prior to 1957. In Kuala Lumpur, the Muslim Welfare Committee organised a program between a religious teacher and the nurses to help change their negative image of "an eyesore to the public and a disgrace to their race" (Utusan Melayu, 1953). In 1956, the Commissioner of Religion Terengganu once discussed with the State Medical and Health Officer of Terengganu to provide religious education for nurses to "eliminate suspicion and slander towards them". Hence, weekly religious classes were held every Thursday evening at the Kuala Terengganu General Hospital prayer room, conducted by appointed female religious teachers (Commissioner of Religion of Terengganu, 1956; State Medical and Health Officer of Terengganu, 1956). Unfortunately, it is not known whether the religious classes continued after 1957.

\section{CONCLUSION}

The above account has discussed the cultural factors that likely influenced the unpopularity of nursing as a career choice among Malay women. The discordance between nursing and the Malay culture was likely due to its Western origin resulting in the practice of foreign values in its system when it was introduced in Malaya. The colonial tradition in nursing continued during the early decades of post-independent Malaysia and the remnants are still observable today.

Nursing was incoherent with the local Malay community because of the disinterest in modern healthcare among the Malays, its formal language, training and posting locations, work-related hazards, working hours, knee-length uniform, gender interaction, no-marriage rules during training and the associated social life. Although there were features of nursing that were in accordance with the Malay culture, the unfavourable features exceed them, leading to the general disinterest of Malays to join nursing, in tandem with other non-cultural factors.

The situation improved in the 1970s when the percentage of Malay nurses raised, as shown in Table 1. During the timeframe, numerous changes took place in both the nursing sphere and the Malay culture. The change of the official language, nurse uniforms, establishment of more nursing schools across Malaysia, and precautions to safeguard the nurses' safety made the profession more favourable for the Malays. On 
the other hand, the Malay culture started changing when more Malays adopt modern life: more girls were educated in the modern education system, more women joined the labour workforce and more people trust the modern healthcare system. As the number of Malay nurses increased, the associated social life may likely change and became more friendly towards the Malay culture. The gender-interaction situation, working hours and no-marriage rules did not change, but the combined effects of the transformations of other factors may have been significant enough to tilt the balance. In this light, improvement of the phenomenon of underrepresentation of specific social groups in a workforce requires either a change in the culture of the group to be more congruent with the working environment or the change of the system to accommodate the cultural needs of the social group at work. Changing the culture of the social group requires greater resources to educate the social group, which also takes a lengthier duration.

The working environment that is non-culturally-sensitive may deter the specific social group from participating in the workforce, leading to underrepresentation that may be detrimental to the wellbeing of the social group. Thus, employers ought to be more culturally sensitive by accommodating the cultural needs of their members of staff in order to create a more inclusive workforce.

\section{ACKNOWLEDGEMENT}

I would like to thank the National Archives of Malaysia, the National Library Board of Singapore and the Parliament of Malaysia for providing access to the database and materials for this study. I am also grateful to everyone who provided assistance for the study. Special thanks to the anonymous reviewer whose critical comments have helped improve the quality of this paper.

\section{REFERENCES}

Aris, A. (2014). The evolution and transformation of Baju Kurung in the Peninsular of Malaysia (Unpublished Doctoral thesis). Universiti Teknologi MARA.

Berita Harian. (1957a). Ada-kah nurse tahu dia akan mati? (Did the nurse know that she would die?), p. 1.

Berita Harian. (1957b, December 25). Sebab2 kurang Jururawat (Reasons for insufficient nurses), p. 7. 
Berita Harian. (1958a, June 24). Jururawat yg berdansa ibu2 bapa naik radang (Nurses' dance angers parents), p. 6.

Berita Harian. (1958b, October 7). Perkara ugama (Religious matters), p. 7.

Berita Harian. (1958c, November 1). 3 jururawat ka-Australia (3 nurses going to Australia), p. 2.

Berita Harian. (1959a, May 2). Orang sakit pukul nurse (A patient hit a nurse), p. 5.

Berita Harian. (1959b, September 23). Jururawat di-tikam orang sakit (Nurse stabbed by patient), p. 1.

Berita Harian. (1959c, November 30). Mengapa-kah wanita2 Melayu kurang bekerja diluar? (Why do Malay women less involved in works outside their homes?), p. 6.

Berita Harian. (1959d, December 15). Sharat bahasa ini sekat gadis2 Melayu - PAS (The language pre-requisite deters Malay women - PAS), p. 1.

Berita Harian. (1960, February 20). Kematian kanak2: Melayu lebeh banyak (Child mortality: Malays are greater in number), p.1

Berita Harian. (1962, December 19). Di-hukum kerana chium jururawat di-hospital (punished for kissing nurse at hospital), p. 5.

Berita Harian. (1963a, January 2). Lebeh ramai jururawat akan di-kirim ka-luar negeri untok berlateh (More nurses will undergo training overseas), p. 5.

Berita Harian. (1963b, January 13). Temasha (Festival), p. 10.

Berita Harian. (1963c, April 10). Kelulusan untok jururawat: kesempatan mungkin dibuka untuk pelajar2 sekolah menengah Melayu (Prerequisite for nursing: potential opportunity for secondary Malay school students), p. 7.

Berita Harian. (1963d, June 21). Mengintai jururawat2 mandi - 2 bulan (Peeping bathing nurses - 2 months), p. 1.

Berita Harian. (1963e, July 17). Hantu yang rambut saperti Elvis Presley ganggu juru2 rawat di-Hospital Klang (Ghost with Elvis Presley haunting nurse at Klang Hospital), p. 1.

Berita Harian. (1963f, December 4). Menyediakan ranchangan kesehatan: beberapa kemudahan untok ra'ayat di-seluroh kampong2 (Preparing the healthcare plan: a few facilities for the people in villages), p. 6.

Berita Harian. (1964a, June 10). \$500 denda chium dgn paksa (\$500 fine for nonconsensual kiss), p. 1.

Berita Harian. (1964b, September 15). Kenapa tidak ramai yang mau jadi jururawat? Berita Harian, p. 6.

Berita Harian. (1964c, September 17). Jururawat bersuami luar nikah di-hukum (Nurse with illicit relationship punished), p. 5.

Berita Harian. (1964d, November 2). Kementerian Kesihatan akan menambah kakitangan Melayu (The Ministry of Health will increase the number of Malay staff), p. 3.

Berita Harian. (1965a). Kechurian di-asrama jururawat dan flat (Burglary at nurses hostel and flat), p. 5. 
Berita Harian. (1965b, February 1). Pakaian jururawat menjolok mata, masharakat kesal (Nurse uniform too revealing, the society is dissappointed), p. 6.

Berita Harian. (1965d, October 12). Asrama di-rompak (Hostel robbed)n, p. 5.

Berita Harian. (1966a, April 5). Asrama bidan dan jururawat: surat kapada menteri, p. 2.

Berita Harian. (1966b, November 12). 324 saja dari 3,000 jururawat ia-lah Melayu (Only 324 of 3,000 nurses are Malays), p. 5.

Berita Harian. (1967, July 5). Sebab2 jururawat tidak puas hati di-kampong2 (Reasons for nurses' dissatisfactions in rural areas), p. 3.

Berita Harian. (1968a, March 14). Jururawat balek dari kursus di-Bangkok (Nurses come back from a course in Bangkok), p. 3.

Berita Harian. (1968b, May 25). Kesah suami "berzina" di-bawa dalam mahkamah (The case of husband commiting adultery taken to court), p. 10.

Berita Harian. (1972, December 17). Zaman gadis-gadis Melayu duduk di ceruk dapur dari pagi hingga malam sudah luput masanya, p. 3.

Birks, M. J., Francis, K., Chapman, Y., \& Abdullah, B. F. (2008). From traditional healers to telemedicine: A history of nursing in Malaysia. Singapore Nursing Journal, 35(2), $16-25$.

Chief Medical Officer of Terengganu. (1951, May 19). Letter to the Director of Medical Services of the Federation of Malaya on Memorandum on Nursing Services Terengganu (Ref: Med/Tr.5/81/49).

Chief Medical Officer of Terengganu. (1953, November 17). Letter to the administrative officers and district officers in Terengganu on vacancies for assistant nurses and midwives (Ref: 8 in Med./Tr. 301/52).

Commissioner of Religion of Terengganu. (1956, January 7). Letter to the State Medical and Health Officer of Terengganu on the Proposal of Weekly Religious Classes for Nurses (Ref: No. 1 in P.A. 138/75).

Department of Information Malaysia. (1978). Sidang akhbar Tan Sri Chong Hon Hyan mengenai penukaran pakaian seragam Jururawat Malaysia di Kementerian Kesihatan, Kuala Lumpur (Press conference of Tan Sri Chong Hon Hyan on the transformation of the Malaysian nurse uniform at the Ministry of Health, K. Retrieved September 3, 2017, from http://mylfoto.penerangan.gov.my/stock-photo/sidang-akhbar-tansri-chong-hon-hyan-mengenai-penukaran-pakaian-seragam-jururawat-malaysia-dikementerian-kesihatan-kuala-lumpur-144553.html

Elm, B. V. \& Hirschman, C. (1979). Age at first marriage in Peninsular Malaysia. Journal of Marriage and the Family, 41(Nov), 887-891.

Federal Constitution 1957. (2010). The Commissioner of Law Revision Malaysia.

Foo, B., \& Richards, C. (2004). English in Malaysia. RELC Journal, 35(2), 229-240.

Gidley, J. M., Hampson, G. P., Wheeler, L., \& Bereded-Samuel, E. (2010). Social inclusion: context, theory and practice. The Australasian Journal of University-Community Engagement, 5(1), 6-36. 
Greer, D. B. (1995). Minority underrepresentation in nursing: Socioeconomic and political effects. The Association of Black Nursing Faculty in Higher Education Journal, 6(2), 44-46.

Hassan, H. (2016). A study on the development of Baju Kurung design in the context of cultural changes in modern Malaysia. Wacana Seni Journal of Arts Discourse, 15, 63-94.

Hirschman, C. (1972). Educational patterns in colonial Malaya. Comparative Education Review, 16(3), 486-502.

Hirschman, C. (2016). Gender, the status of women, and family structure in Malaysia. Malaysian Journal of Economic Studies, 53(1), 33-50.

Idris, M. R. (2016). Perkembangan pendidikan wanita Melayu di Negeri-negeri Melayu Bersekutu, 1896-1941. Universiti Malaya.

Kortteinen, S. (2008). Negotiating ethnic identities: Alcohol as a social marker in East and West Malaysia. Akademika, 72(1), 25-44.

Lee, N. (2014). Transformasi fesyen pakaian Muslim di Semenanjung Tanah Melayu, 19301940 (Muslim fashion transformation in the Malay Peninsula, 1930-1940). Jurnal Perspektif, 6(3), 68-80.

Loftin, C., Newman, S. D., Dumas, B. P., Gilden, G., \& Bond, M. Lou. (2012). Perceived barriers to success for minority nursing students: An integrative review. ISRN Nursing, 2012, 806543.

Malaysian Nursing Union. (1972). Sixth Bienniel Report (1970-1971). Malaysian Nursing Union.

Mariam, M. C. (1959, December 9). Kebanyakan anak2 ingin jadi guru yang berjasa. Berita Harian, p. 6.

Medical and Health Department. (1950). Schemes of Service for Nurses. Medical and Health Department.

Medical and Health Department. (1958). Federal Government Press Statement on World Health Day - Progress in Nursing: 1948-1958 (Ref: D.INF. 3/58/162 (HEALTH)).

Medical and Health Department (1958). Report of the Medical Department 1957. Medical and Health Department.

Medical and Health Department (1959). Report of the Medical Department 1958. Medical and Health Department.

Medical and Health Department. (1960). Report of the Medical Department 1959. Medical and Health Department.

Ministry of Health Malaysia. (1973), Annual Report 1971-1972. Ministry of Health Malaysia.

Ministry of Health Malaysia. (1975). Annual Report 1973-1974. Ministry of Health Malaysia. Ministry of Health Malaysia. (2017). Exhibition of the Transformation of Nurses Uniform in Ministry of Health Malaysia. Ministry of Health Malaysia. 
Othman, M. A., \& Lee, P. L. (2014). Sejarah pendidikan di Tanah Melayu dari tahun 19001941. Jurnal Pendidikan Dedikasi, 8(1), 1-18.

Parliament of Malaysia. (1959). Parliamentary debates official report: House of Representatives (3 December, 1959). Kuala Lumpur.

Parliament of Malaysia. (1964). Parliamentary debates official report: Senate (25 November, 1964). Kuala Lumpur.

Parliament of Malaysia.(1965). Parliamentary debates official report: House of Representative (4 June, 1965). Kuala Lumpur.

Parliament of Malaysia. (1972). Parliamentary debates official report: Senate (14 January, 1972). Kuala Lumpur.

Parliament of Malaysia. (1973a). Parliamentary debates official report: House of Representatives (3 December 1973). Kuala Lumpur.

Parliament of Malaysia. (1973b). Parliamentary debates official report: Senate (3 May 1973). Kuala Lumpur.

Parliament of Malaysia. (1974). Parliamentary debates official report: House of Representatives (3 December 1974). Kuala Lumpur.

Parliament of Malaysia. (1975a). Parliamentary debates official report: House of Representatives (2 April, 1975). Kuala Lumpur.

Parliament of Malaysia. (1975b). Parliamentary debates official report: Senate (22 July, 1975). Kuala Lumpur.

Parliament of Malaysia. (1975c). Parliamentary debates official report: Senate (24 July, 1975). Kuala Lumpur.

Parliament of Malaysia.(1976). Parliamentary debates official report: House of representatives (9 November, 1976). Kuala Lumpur.

Parliament of Malaysia. (1977a). Parliamentary debates official report: House of Representatives (19 July, 1977). Kuala Lumpur.

Parliament of Malaysia. (1977b). Parliamentary debates official report: Senate (20 April, 1977). Kuala Lumpur.

Parliament of Malaysia. (2005). Parliamentary debates official report: Senate (18 May 2005) (Vol. 10). Kuala Lumpur.

Phillips, J. M., \& Malone, B. (2014). Increasing racial / ethnic diversity in nursing to reduce health disparities and achieve health equity. Public Health Reports, 129(Suppl 2), 4550.

Prime Minister's Office (1976). The Third Malaysia Plan. Prime Minister's Office.

Putten, J. van der. (2014). "Dirty dancing" and Malay anxieties: the changing context of Malay Ronggeng in the first half of the twentieth century. In B. Barendregt (Ed.), Sonic Modernities in the Malay World: A History of Popular Music, Social Distinction and Novel Lifestyles (1930s-2000s) (pp. 113-134). Brill.

Ramli, M. A. (2004). Konsep masyarakat Melayu mengenai hubungan gender. Jurnal YADIM, Dec, 141-153. 
Saadon, R., Ariffin, K., \& Saat, I. (2016). Perkembangan pendidikan orang Melayu di Malaya sebelum kemunculan Western-tupe Education (The educational development of the Malays in Malaya before the emergence of Western-type-education). Jurnal Perspektif, 8(2), 79-96.

Secretary of the Kuala Terengganu branch of United Malays National Organisation. (1954, July 24). Letter to the State Mufti of Terengganu on the Issue of Nurses (Ref: No.26 in Ch. UMNO. B.K.T 26/53).

Selangor State Council. (1933, October 16). Extract from the minutes of the 343rd Meeting of the Selangor State Council.

Shawal, Z. (1994). Busana Melayu. Jabatan Muzium Malaysia.

State Medical and Health Officer of Perak. (1956, November 27). Letter to the State Secretary of Perak on the establishment of a school in Perak to train Assistant Nurses in Malay (Ref: Med/Pk.15/194/56).

State Medical and Health Officer of Selangor. (1957, February 21). Letter to the State Secretary of Selangor on the Resignation of a Nurse to Get Married (Ref: MED/ SEL/2/2247).

State Medical and Health Office of Selangor (1938, February 21). Minute paper on Malay nurses (Ref: S544/35).

State Medical and Health Officer of Terengganu. (1956). Memo on the Weekly Religious Class at Kuala Terengganu General Hospital Prayer Room (Ref: No. 1 in Med/Tr. 21/1956).

State Mufti of Terengganu. (1954a, January 8). Response Letter to the State Secretary of Terengganu on the Issue of Nurses (Ref: No. 2 in P.A. 146/73).

State Mufti of Terengganu. (1954b, August 2). Response Letter to the Secretary of the Kuala Terengganu branch of United Malays National Organisation on the Issue of Nurses (Ref: No. 5 in P.A. 146/73).

State Secretary of Terengganu. (1953, December 30). Letter to the State Mufti of Terengganu on the Issue of Nurses (Ref: No. 19 in SKTr. 106/53).

Swettenham, F. A. (1895). Malay Sketches. John Lane.

Tahir, E. S. M. (2003). Ayah saya pejuang menentang Belanda (My father was a fighter against the Dutch Public Health Rep . Jan-Feb 2014;129 Suppl 2(Suppl 2):45-50. doi: $10.1177 / 00333549141291 \mathrm{~S} 209$. Increasing racial/ethnic diversity in nursing to reduce health disparities and achieve health equity Janice M Phillips 1, Beverly Malone 2). In E. S. M. Tahir (Ed.), Bagaimana akhirnya saya bertudung (How I finally became a hijabi) (pp. 96-110). PTS Millenia Sdn Bhd.

Tan, Y. S. (2009). Perkembangan pendidikan di Malaysia: peranan Lim Lian Geok dan Aminuddin Baki. Ngan Pendidikan Di Malaysia Jurnal Terjemah Alam and Tamadun Melayu, 1, 139-166.

The Straits Times. (1965c, May 3). Nurses' Week dance date, p. 5.

Utusan Melayu, 1953. (1953, Dec 18). Hospital staff. 
Williams, S. D., Hansen, K., Smithey, M., Burnley, J., Koplitz, M., Koyama, K., ... Bakos, A. (2014). Using social determinants of health to link health workforce diversity, care quality and access, and health disparities to achieve health equity in nursing. Public Health Reports, 129(Suppl 2), 32-36. doi:10.1177/00333549141291S207

Yusoff, M. N., Osman, M. K. A., Rofie, M. K., Abdul Rahman, M. N., and Md Zain, A. (2004). Pembudayaan nilai Islam dalam rekabentuk rumah tradisional masyarakat Melayu (Islamic values in the design of traditional Malay houses). In Paper presented at the International Seminar on the values of post-modern communities (4-6 September 2004) (pp. 1-11). Langkawi. 